\title{
Political Dispensation and its Effects on the Early Childhood and Primary Education in Nigeria
}

\author{
Dr. Mrs. Grace Oluremilekun Akanbi \\ Department of Educational Foundations \\ School Of Education, Emmanuel Alayande College Of Education, P.M.B. 1010, Oyo, Oyo \\ State, Nigeria \\ Email: Oluremiakanbi@ Ymail.Com, Oluremiakanbi2004@ Yahoo.Co.Uk
}

Accepted: August 27, 2012 Published: September 29, 2012

Doi:10.5296/jsr.v3i2.2485 URL: http://dx.doi.org/10.5296/jsr.v3i2.2485

\begin{abstract}
The importance of education to human beings cannot be overemphasized. It is seen, regarded and accepted to some extent, as the quickest way to eradicate poverty and ills in the society. There are a lot of international human rights instruments that provide for education as a fundamental right. These include the Universal Declaration of Human Rights (1948), the International Covenant of Economic, Social and Cultural Rights (1966) and the African Charter on Human and Peoples Rights (1981). To this end, various nations have given priority to education and have developed mechanisms to operate the system for effective impartation and acquisition of knowledge and skills that will help the learners to be useful for themselves and to the society at large. Pre-Primary and Primary levels of education are the most crucial because they form the foundation upon which all other levels depend to thrive. It could be seen as the proverbial 'ketekete' (donkey - the burden bearer). However, several political dispensations had affected these levels of education in Nigeria. This paper, therefore, highlights the various political dispensations/phases of early childhood and primary education in Nigeria from 1842 to 2011. It discusses the various programmes at various dispensations, how they were developed, operated, managed, sustained and the outcome or the effects of each dispensation on the general development and quality of education in Nigeria. Some hindrances to qualitative pre-primary and primary education were also discussed. The paper also suggests among others, that education sector should be a zone for professionals.
\end{abstract}

Keywords: Early Childhood, Primary and Pre-Primary Education, National Policy on Education (NPE), Political dispensation, Universal Basic Education

\section{Introduction}

Before the introduction of Islamic and Western education as rightly observed by the Federal Ministry of Education (2007), every community in Nigeria had its traditional pattern of education that ensured socialization and intergenerational transmission of cultural heritage. 


\section{Mll Macrothink}

Journal of Sociological Research

ISSN 1948-5468

2012, Vol. 3, No. 2

With the coming of Islam, parts of the country assimilated Islamic education into their indigenous systems and developed highly sophisticated and organized literacy civilization. Western education on the other hand began as an offshoot of Christian missionary efforts, and therefore, was slow in penetrating into the areas of strong Islamic influence, while areas with strong Christian influence readily embraced the new form of colonial/western education. The historical incidents, turned out to be political, has had the effect of polarizing the country in educational terms, giving rise to the well documented and well orchestrated phenomenon of educational imbalance. The phenomenon has remained an intractable challenge to the educational development in the country. Suffice to say that this situation had been manipulated by the colonial government and is being entrenched further by subsequent policies at regional, state and national levels.

Nigeria got her independence from Britain on October 1, 1960 and by implication, she is free to develop and manage her early childhood and primary education programmes. But the high hopes raised by political independence were not realized due to the political instability that set in with the military coups d'etat (with only four-year interregnum of civil rule:1979-1983) that characterized the first three decades of national sovereignty. In fact, between the Independence in 1960 and 1999, when Nigeria rejoined the comity of democratic nations, the military had ruled the nation for thirty years. From three regions at Independence in 1960, and later four with the creation of Mid West Region in 1963, Nigeria progressively let go the regional structure to have 12 states in 1967, 19 in 1976, 21 in 1987, 30 in 1991, and finally to 36 states (and a Federal Capital Territory) by 1996. Each state is divided into a number of local governments, of which there are at present, a total of 774 in the entire Federation of Nigeria. All these changes in political and administrative structures, without doubt, had their effects on early childhood/pre-primary and primary education in terms of funding, staffing, accommodation and running of the schools. In this paper, pre-primary education will be used interchangeably with early childhood education. Laying emphasis on western education, this paper focuses its discussion on;

- Colonial Dispensation and Primary Education in Nigeria. (The Winner takes it all)

- First Government Intervention in Education in Nigeria.

- Regionalization and Mass Primary Education

- The 1969 Curriculum Conference and the National Policy on Education (NPE).

- Primary Education in Post Colonial Dispensation in Nigeria - 1976 Universal Primary Education (UPE)

- Early Childhood Education (ECE) in Nigeria

- Universal Basic Education (UBE)

- Features of Political Dispensation and its Effects on Pre-Primary and Primary Education in Nigeria. 


\section{Colonial Dispensation and Primary Education in Nigeria (The Winner takes it all)}

The arrival of various missionary bodies in Nigeria between September 1842 and 1860 and the introduction of western education in Nigeria have been well documented by Otonti 1965; Fafunwa 1974; Taiwo 1980; Ukeje \& Aisiku 1982; Osokoya 1989. The Wesleyan Methodist Missionary Society led by the Revd. Thomas Birch Freeman, accompanied by William de Graft arrived in Badagry on September 24, 1842. The first school was established by Mr. and Mrs. De Graft in Badagry and was named 'Nursery of the Infant Church'. The Church Missionary Society (C.M.S.) also arrived in Badagry in 1843 and moved to Abeokuta in 1846 where they founded two schools, one for boys and the other for girls under the supervision of Samuel Ajayi Crowther and his wife. Crowther also opened the first school in Onitsha in December 1858 for girls between 6 and 10 years old. Missionary effort in Western Nigeria was soon followed by enterprises in the Niger Delta and Eastern Nigeria. In 1847, the United Free Church of Scotland started work in Calabar. In 1887, the Qua Iboe Mission started work in the Eket and Uyo districts, also in the primitive Methodists in Calabar and Owerri Provinces in 1894.

Because the primary objective of the early Christian Missionaries was to convert Africans to Christianity via education, the establishment of missions was always followed by the opening of primary schools. This was a fundamental problem in the first instance; because sound education was not the primary aim but rather, education that will allow the recipient to serve the providers. Primary Education between 1842 up to 1887 was purely a Missionary affair, curricula and other elements were largely determined by each denomination to suit their needs and no mission talked about early childhood education because it has no direct usefulness to their 'business'. Even, the colonial government paid little attention to education and was merely interested in using the products of the mission schools as clerks, messengers and interpreters.

\section{First Government Intervention in Education in Nigeria}

The first government direct intervention in the management and funding of primary education came through the 1882 Education Ordinance, which applied to all of British West African countries. This Ordinance provided for a General Board of Education and Local Boards of Education, classification of schools into government and assisted schools, freedom of parents to choose religious instruction for their children and wards, grants for buildings and teachers' salaries, conditions of grants-in-aid to private schools, appointment of inspectors, special grants to industrial schools, admission of indigent children into government and assisted schools, and grants to training colleges and institutions for teachers, among others. It also provided guidelines for examination of pupils and the certification of teachers. Other ordinances were also promulgated - 1887as well as 1926. 
By the end of 1912, there were fifty-nine government primary schools and ninety-one different mission schools aided by Government in Southern Nigeria an indication of expansion of formal primary education. (Source: Fafunwa, 1974)

It should be noted, however, that while formal western primary education was thriving in Southern Nigeria, traditional and Quranic education were taking firm root in the North, and this accounted for the educational gap between the South and the North in Nigeria up to date.

\section{Regionalization and Mass Primary Education}

Development in the political sphere occasioned by the Richards Constitution of 1946, according to Osokoya (1987) started to put Nigeria firmly on the path to political independence. It divided Nigeria into three regional administrative units, decentralized educational administration and classified it as a regional service. ActionAid (2006), noted that one recurrent criticism of Education up to the time when the - regions, East, North and West were created was that education was elitist and hardly affordable by a majority of the people. Thus the regions were faced with the challenge of providing education for the majority of the people. To tackle this problem, the various regional governments made laws which became the basis of regional activities and policies in education. The Western Region made the first attempt in 1955 by the proclamation of a free, Universal and Compulsory Primary Education (UPE) scheme for the entire region. This was followed by the Eastern Region in 1957 and the Lagos City Council also in 1957. The North only passed an education law in 1962 establishing a partnership between the government and the voluntary agencies in an attempt to develop a public system of primary education in which the government would be the leading partner with the Minister of Education having overall responsibility for the promotion of primary education.

The regionalization of education during this period increased enrolment in primary schools in the North from 66,000 in 1947 to 205,769 in 1957; in the West from 240,000 in 1947 to 982, 755 in 1957; and in the East from 320,000 to 1,209,167 for the same period (Fafunwa 1974). The political Independence that followed in 1960 no doubt also affected the operation of primary schools in Nigeria. Ukeje and Aisiku (1982) observed that the pace of educational expansion set in motion by UPE schemes of various regions lost its momentum in the 1960s. The civil war (May 1967 to January 1970) aggravated the decline; also was the apparent shift in emphasis from quantity to quality that led to the closure/merging of schools. However, in the early 1970 s as a result of the end of the civil war, the number of primary schools rose again. The 1975-80' Development plan ushered in a most profound boom for primary education in the country. The plan explicitly stated; UPE is a pre-requisite for equalization of opportunities for education across the country in all its known facets.

\section{The 1969 Curriculum Conference and the National Policy on Education (NPE)}

The report of the 1969 National Curriculum Conference was the first national effort to change 


\section{Macrothink}

the colonial orientation of the Nigerian educational system. The colonial education policy was still in use until 1977 when a unified National Policy on Education (NPE) emerged. This was an outcome of the 1969 conference. The NPE revised in 1981 and 2004 states in clear terms that pre-primary education is the education given in an educational institution to children aged 3 to 5 plus prior to their entering the primary school. The purpose of pre-primary education according to NPE should be:

(a) effecting a smooth transition from the home to the school;

(b) preparing the child for the primary level of education

(c) providing adequate care and supervision for the children while their parents are at work (on the farms, in the markets, offices, etc.);

(d) inculcating social norms;

(e) inculcating in the child the spirit of enquiry and creativity through the exploration of nature, and the local environment, playing with toys, artistic and musical activities, etc.;

(f) teaching co-operation and team spirit;

(g) teaching the rudiments of numbers, letters, colour, shapes, forms etc. through play; and

(h) teaching good habits, especially good health habits.

It needs to be stated that Primary Education is also referred to in the document as education given in an institution for children aged normally 6 to $11+$ and the rest of the education system is built upon it. It could be likened to 'ketekete' (donkey) that bears burden. (see figure 1) 


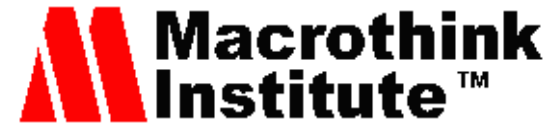

Journal of Sociological Research

ISSN 1948-5468

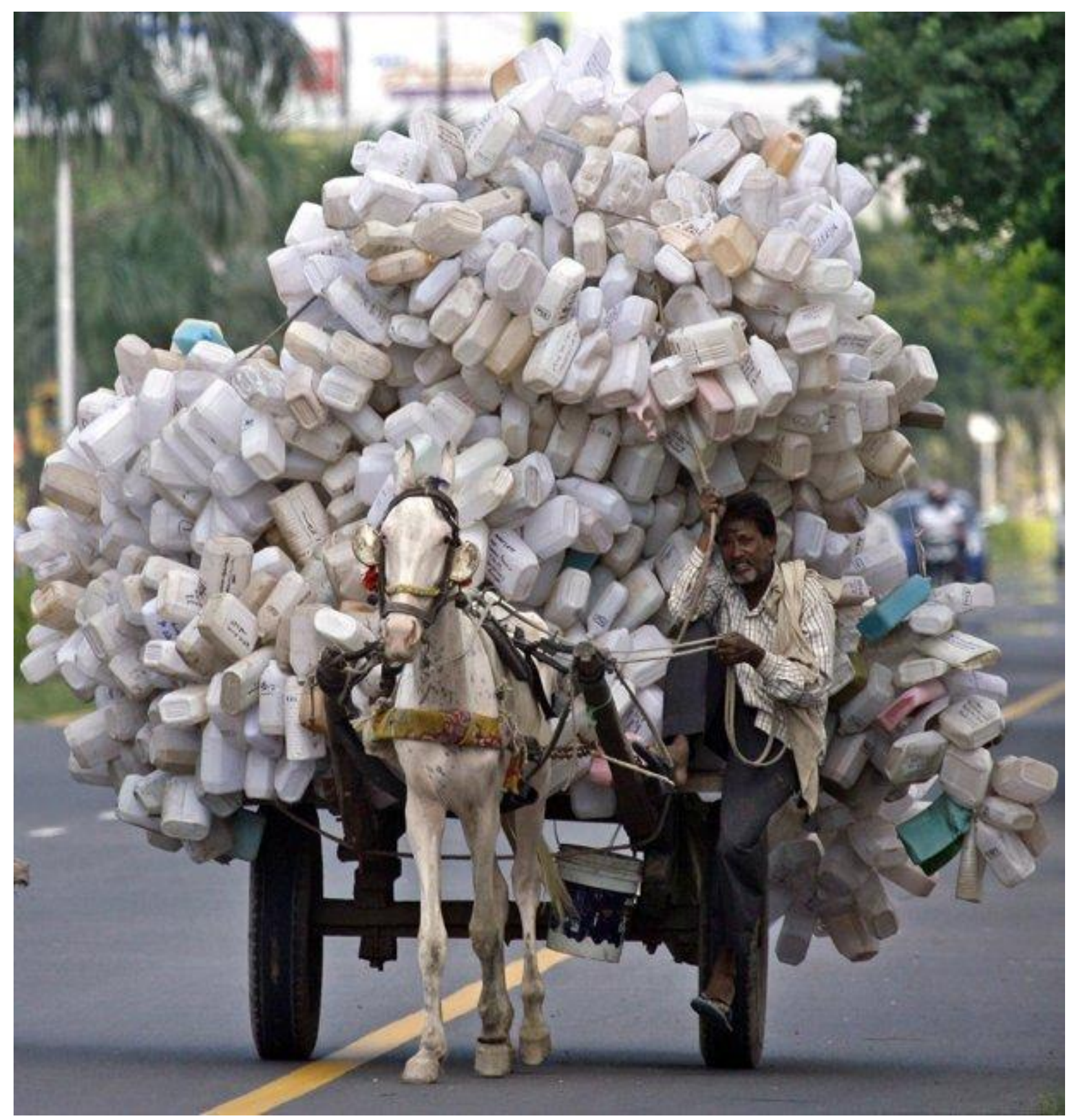

Figure 1: Ketekete (just like the primary school) Source: Unknown

Because it is the key to the success or failure of the whole system, it must fulfill two basic functions:

(1) prepare children for life,

(2) give those with the necessary background the opportunity to proceed to secondary school. and the objectives are:

(a) the inculcation of permanent literacy and numeracy and the ability to communicate effectively; 
(b) the laying of a sound basis for scientific and reflective thinking;

(c) citizenship education as a basis for effective participation in and contribution to the life of the society;

(d) character and moral training and the development of sound attitudes;

(e) developing in the child the ability to adapt to his changing environment;

(f) giving the child opportunities for developing manipulative skills that will enable him to function effectively in the society within the limits of his capacity;

(g) providing basic tools for further educational advancement, including preparation for trades and crafts of the locality.

\section{Primary Education in Post Colonial Dispensation in Nigeria - 1976 UPE}

The dual ownership and control of schools (public/private) in Nigeria lasted till 1970. The Federal Military Government enacted the "Schools Takeover Validation Decree" No. 41 of 1977 which reinforced the powers of State government to take over all schools to ensure effective implementation of the national programme on UPE that was launched in 1976. However, between the late 1970s and 1985, permission was granted to private proprietors to establish schools alongside public schools and they are fee paying schools (FME 2008).

The provision of basic education, especially at the primary school level, to the vast majority of the intending pupils has been a major challenge for successive governments. Many children of school age could not attend school for so many reasons, including problem of access and inability of their parents to pay fees. The military takeover of voluntary agency primary schools also failed to increase and equalize educational opportunities. It was against this background that the Federal Government in 1976 singled out primary education for intervention by launching the Universal Primary Education (UPE) scheme. The overall purpose was to boost school enrolments throughout the country and correct educational imbalances between the different parts of the country and boys and girls "The scheme raised primary school enrolment from six million in 1975/76 to eight million during the first year of the scheme in 1976/77 and to 12.5 million in 1979/80" (Taiwo 1980).

\section{Early Childhood Education (ECE) in Nigeria}

Early Childhood Care and Development (ECCD) is often misinterpreted to mean merely an academically-oriented pre-school programme. In fact, the term is used to describe a range of services that promote those conditions of care, socialization and education in the home or community that enhances a child's total development. In Nigeria, such education terminates at age five and it is the very foundation of all levels of educational attainment for all who are opportune to acquire it.

According to Penn (2008), the scope of early education and care interventions are defined in the Education for All Global Monitoring Report (referred to in the report as Early Childhood Care and Education (ECCE) as follows: 


\section{Macrothink}

- ECCE supports children's survival, growth, development and learning-including health, nutrition and hygiene and cognitive, social, physical and emotional development - from birth to entry into primary school in formal, informal and non-formal settings.

- ECCE programmes encompass very diverse arrangements from parenting programmes to community-based childcare, centre based provision and formal pre-primary education, often in schools.

- Programmes typically aim at two age groups: Children under three and those ages three to primary school entry.

Prior to the formulation of the National Policy on Education (NPE), there was little or no clear cut operation of early childhood education as a separate unit in the primary schools. In fact, in the early years of Western Education, pupils who wished to enroll in schools were asked to touch their left hear with their right hand, not minding the age of such child. If the hand cannot touch it, he/she is sent back home until another year. It could, therefore, be observed that progress towards achieving the goals of formal Early Childhood Care and Education has been very slow. This is because participation in Early Childhood Care and Education for children between ages zero and three years has been private sector driven and takes place in informal settings such as private homes, play groups, day-care centres, and crèches while government intervention in ECCE has been that of setting and regulating standards with political undertones.

Recent trends, however, show that a few States and Local Governments are beginning to introduce pre-primary and primary linkages. The Education Sector Analysis (ESA) studies on pre-primary education provides a clear picture of provisions for early childhood care and development in Nigeria as shown in table 1 below. 
Table 1: Enrolment in Formal Pre-Primary Schools by State, 2004/2005

\begin{tabular}{|c|c|c|c|c|c|c|c|c|c|}
\hline State & Boys & Girls & Total & $\begin{array}{l}\text { \%Girls } \\
\text { Enrol }\end{array}$ & State & Boys & Girls & Total & $\begin{array}{l}\text { \% Girls } \\
\text { Enrol }\end{array}$ \\
\hline Abia & 47517 & 47082 & 94599 & 49.77 & Kano & 22237 & 21675 & 43912 & 49.36 \\
\hline Adamawa & 10809 & 10108 & 20917 & 48.32 & Katsina & 5545 & 4695 & 10240 & 45.85 \\
\hline Akwa Ibom & 30866 & 32097 & 62963 & 50.98 & Kebbi & 5946 & 4624 & 10570 & 43.75 \\
\hline Anambra & 58610 & 56863 & 115473 & 49.24 & Kogi & 15972 & 14927 & 30899 & 48.31 \\
\hline Bauchi & 14973 & 12715 & 27688 & 45.92 & Kwara & 18303 & 16929 & 35232 & 48.05 \\
\hline Bayelsa & 4625 & 4523 & 9148 & 49.44 & Lagos & 71038 & 69192 & 140230 & 49.34 \\
\hline Benue & 17867 & 17010 & 34877 & 48.77 & Nasarawa & 13419 & 12282 & 25701 & 47.79 \\
\hline Borno & 13926 & 10728 & 24654 & 43.51 & Niger & 30035 & 25764 & 55799 & 46.17 \\
\hline Cross River & 48865 & 49463 & 98328 & 50.30 & Ogun & 50992 & 49143 & 100135 & 49.08 \\
\hline Delta & 31896 & 30821 & 62717 & 49.14 & Ondo & 41138 & 41037 & 82175 & 49.94 \\
\hline Ebonyi & 7931 & 7700 & 15631 & 49.26 & Osun & 33595 & 32837 & 66432 & 49.43 \\
\hline Edo & 19701 & 19294 & 38995 & 49.48 & Oуо & 96903 & 96719 & 193622 & 49.95 \\
\hline Ekiti & 11967 & 11825 & 23792 & 49.70 & Plateau & 15859 & 15476 & 31335 & 49.39 \\
\hline Enugu & 32855 & 32104 & 64959 & 49.42 & Rivers & 6380 & 6056 & 12436 & 48.70 \\
\hline FCT & 1465 & 1340 & 2805 & 47.77 & Sokoto & 41095 & 24046 & 65141 & 36.91 \\
\hline Gombe & 11159 & 10780 & 21939 & 49.14 & Taraba & 12595 & 10854 & 23449 & 46.29 \\
\hline Imo & 57685 & 56129 & 113814 & 49.32 & Yobe & 5105 & 4319 & 9424 & 45.83 \\
\hline Jigawa & 5551 & 4328 & 9879 & 43.81 & Zamfara & 4269 & 2762 & 7031 & 39.28 \\
\hline Kaduna & 37781 & 35549 & 73330 & 48.48 & Total & 956475 & 903796 & 1806271 & 48.58 \\
\hline
\end{tabular}

\section{Source; Federal Ministry of Education 2006}

Despite the above enrolment, the situation of children in the pre-primary education sector is not cheering as less than $20 \%$ of children ages 0-5 years are attending any form of organized child care programme or pre-schools. Despite efforts to ensure that public schools have Early Childhood Care Development Education (ECCDE) centres, access remain a major issue. There is a wide disparity between the expected and actual enrolment figures. According to the 2009 Education Road Map, the expected enrolment in ECCDE is 22 million but the actual is only 2.02 million. Due to long neglect of this area, the provision of ECCDE has been a near exclusive preserve of the private providers. As a result, it has been available mainly to those whose parents could afford the services.

Although the NPE (2004) had described pre-primary education and given its purposes, the National Policy for Integrated Early Childhood Development in Nigeria was just published in 
2007. The political will of those concerned had been a major problem. Often times, good policies are fashioned out in the education sector but the implementation had always been bedeviled by corruption and self centeredness on the part of those that are supposed to implement the policies.

\section{Universal Basic Education (UBE)}

The Universal Basic Education launched in September 1999 by Obasanjo led administration is a product of the Jomtien Conference on Education for All (EFA) of 1990 especially goal one; expanding and improving comprehensive early childhood care and education especially for the most vulnerable and disadvantaged children and goal two; ensuring that by 2015 all children, particularly girls, children in difficult circumstances and those belonging to ethnic minorities have access to and complete free and compulsory primary education of good quality. The UBE programme is a reform measure which is aimed at addressing inequality in educational opportunity and addressing the distortion in the basic education sub-sector. It also reinforces the implementation of the National Policy on Education and ensures access, equity and quality of basic education throughout the country, especially at the pre-primary and primary levels. Though, the UBE in Nigeria extends to the Junior Secondary School, it boosted enrolment in the primary schools. The Millennium Development Goals report on the achievement of UBE in terms of enrolment trends from 1999 - 2003 show consistent increase from 7\%, 8\%, 11\% and 44\% in 2000, 2001, 2002 and 2003 respectively (Obanya 2007). This implies that more children have opportunities to enroll and attend school. Schools are available within easy reach of children and there is adequate number of classrooms. This is in line with the Federal Ministry of Education's submission on progress in Basic Education as indicated in the table below.

Table 1: Summary of Number of Schools, Classrooms and Enrolment by Gender, 1999-2005

\begin{tabular}{|l|l|l|l|l|l|}
\hline YEAR & $\begin{array}{l}\text { NO. OF } \\
\text { SCHOOLS }\end{array}$ & $\begin{array}{l}\text { NO. OF } \\
\text { C/RMS }\end{array}$ & MALE & FEMALE & TOTAL \\
\hline 1999 & 49,326 & 102,943 & $10,058,434$ & $7,848,894$ & $17,907,328$ \\
\hline 2000 & 49,326 & 116,101 & $10,738,029$ & $8,413,413$ & $19,151,442$ \\
\hline 2001 & 49,306 & 124,229 & $10,583,411$ & $8,457,812$ & $19,041,223$ \\
\hline 2002 & 50,516 & 116,827 & $11,015,011$ & $8,791,071$ & $19,806,082$ \\
\hline 2003 & 59,131 & 111,257 & $14,366,513$ & $11,338,280$ & $25,704,793$ \\
\hline 2004 & 60,188 & 254,319 & $11,824,494$ & $9,571,016$ & $21,393,510$ \\
\hline 2005 & 60,188 & 254,319 & $12,189,073$ & $9,926,359$ & $22,115,432$ \\
\hline
\end{tabular}

\section{Source: Federal Ministry of Education, Nigeria (2007)}

But according to the National Policy for Integrated Early Childhood Development in Nigeria (2007), 30\% of 6-11 year old children are not in school and the Report of the Vision 2020 National Technical Working Group on Education Sector (2009), the rate of access to primary education for the six geo-political zones were South-West $88.0 \%$; North-central $79.7 \%$ and 
North-west 76.4\%. The North East (71.9\%), South-South (71.7\%) and South-East $(60.6 \%)$ had rates below the National average of $75.9 \%$ (74.6 urban and 56.6\% rural). Why? Igbuzor (2006) provided some likely answers; cost of schooling including cost of books, stationery and basic equipment, uniforms, transportation, mid-day meals and Parent/Teachers Association (PTA) fees. Conversely, according to him, it has been documented that whenever user fees are abolished, enrolment increases. An example is Tanzania which eliminated fees for primary education in January 2002 with the support of the World Bank and enrolment surged by as much as 1.5 million children.

\section{Features of Political Dispensation and its Effects on Pre-Primary and Primary Education in Nigeria}

From the highlights of some major political dispensations in Nigeria, it could be seen that pre-primary and primary education had passed through various phases; this in no doubt had affected and is still affecting its provision and management. Several efforts that were made during each dispensation to provide access are commendable, but there is room for improvement if the political will is there. Though the word dispensation in the context of our Conference Theme seems to mean a period or a season, in the course of preparing this paper, especially talking about effects of political dispensation, I have been tempted to agree with and use dispensation as "special permission to do something that is normally not allowed" - just as a dictionary defined it. I see periods of politics as mad periods when the unexpected and unimaginable can happen yet people still feel comfortable; or how would you expect a group of politicians to obtain a bank loan to the tune of 40 billion Naira to increase their personal allowances in a nation where children are using shade of trees as classroom and where common chalk and duster are not available in schools. I also hope that we are aware that the Economic and Financial Crimes Commission (EFCC) is currently trying a former Governor and four of his aides for embezzling 5 billion Naira UBE fund in an educationally disadvantaged State, what an irony! Effects of political dispensation on early childhood and primary education are inexhaustible and may not be a subject of discussion in a single paper like this. This paper, therefore, had tried to identify some features of political dispensation so as to discuss very few of the notable effects, namely;

\section{Under-funding and Corruption}

It could be noticed that budgetary allocation to defense/security is always high. But may be our leaders would need to be tutored that effective education could reduce crime better than uncountable personal security aides. There is popular saying in Yoruba land that 'Omo ti a ko ko ni yoo gbe ile ti a ko ta' (literarily translate as 'A child we refuse to train will eventually sell-off the house we have built.') We were at the Rutgers University in Newark, New Jersey in the United States of America and nobody knew that the Governor was there until he was formally introduced. He had no tension because education had played its role. Under-funding of the education sector is a characteristic feature of political dispensations. The Presidential Task Team on Education noted that "Education budget, as a proportion of total federal spending, is some 
$7.6 \%$ (average from 2008 to 2010). It is roughly 5\% of total federal capital budget and $11 \%$ of total budget." Whereas, according to United States of America International Development (USAID), to reach the EFA goals, it is estimated that half of the education budget needs to go to the primary education sub-sector. But for now only about $35 \%$ of the education budget is currently devoted to primary education. The question to ask here is; is the whole $35 \%$ truly being spent on primary education? Corruption is a major problem in this dispensation. Contracts awarded for construction of classrooms are inflated to accommodate 'brown envelopes' for various categories of officers in the ministry and, even in the school itself. Money that could have built two blocks of classroom may not even be sufficient for foundation laying ceremony.

\section{Poor/Inadequate Infrastructure and Window-Dressing}

The primary school infrastructure has seriously deteriorated with many of the existing structures needing repairs. Unfortunately, window-dressing is also a feature of political dispensation and it is terribly affecting both pre-primary and primary education. UBEC (2010) in its report on the utilization of the UBE Intervention and Counterpart Funds in 36 States and FCT gave the following; (An extract is presented in the table below and we must ask ourselves; out of how many or what percentage?)

\section{Table 3: Extract from UBEC Report 2010}

\begin{tabular}{|l|l|c|}
\hline 1. & Infrastructural Development & \\
a & Construction of new classrooms & 41,009 \\
b & Renovations (classrooms) & 59,444 \\
c & Provision of furniture (Pupils\&Teachers) & $1,139,196$ sets \\
d & Construction of Toilets & 14,769 \\
e & Sinking of boreholes & 996 \\
\hline 2. & Provision of Instructional/Play Materials & $77,570,540$ \\
\hline 3. & Teacher professional development & $1,493,352$ teachers trained \\
\hline 4. & Provision of primaries 4 \& 5 Textbooks in & $16,356,812$ \\
& Mathematics, English Language and Activity-Based & \\
\hline
\end{tabular}

Source: http://ubeconline.com/index 2. html page 2 of 3

When situations in schools are to be presented to the world, the picture of the best or few newly renovated schools and well fed children are presented as if all is well. According to the report of Vision 2020 National Working Group on Education Sector (2009), the learning conditions in schools are alarming. Paucity of teaching materials (few textbooks, in many schools no charts or teaching aides, children in many cases having only their exercise books for taking notes), absence of adequate furniture in some schools, over-crowded classrooms, lack of ventilation, and generally run-down condition of many of the school buildings. In this same environment where the above situations exist, you will now see a single individual either a politician or connected to a politician or a contractor establishing a private nursery and primary school with a state of the 
art infrastructure. This may prompt you to ask; if an individual could do this why not the government? Of course you know the answer!

\section{Overlapping Management}

Basic Education, which includes the primary education, is managed by the State Ministry of Education (SME), State Universal Basic Education Board (SUBEB) and the Local Government Education Department with the Federal Ministry of Education providing policy guidelines. While the Federal Government, through the Ministry of Education and the Universal Basic Education Commission, provides leadership through broad policy guidance, setting national standards and providing a regulatory framework. These efforts are often confounded by at least 21 parastatals which are often created to accommodate the interest of the politicians -with overlapping mandates in the education sector. Structures are over-bureaucratized, too centralized and lead to duplication, ineffectiveness and a lack of decisive action. Adding to this complexity is the relative independence of each SME and SUBEB, creating a situation wherein no two States have exactly the same systems for the provision of quality basic education. The recent committee on rationalization of parastatals, however, may work for the good of the education sector if its report is allowed to see the light of the day.

\section{Lack of interest in Programmes that will benefit Children of the Poor in Primary Schools}

In Nigeria, according to Federal Ministry of Education (2007), over 90\% of morbidity and $80 \%$ of mortality in under-5 children arise from four causes: malaria, vaccine preventable diseases, diarrhea and acute respiratory infections. Malnutrition is an attributable cause in over $50 \%$ of such mortality. In the realization of the central role of nutrition to education, the Federal Government of Nigeria in collaboration with New Partnership for African Development (NEPAD), World Food Programme (WFP), United Nations International Children's Fund (UNICEF) and other International Development Partners (IDPs) developed the Home Grown School Feeding and Health Programme (HGSFHP). The programme was launched on Monday 26 September, 2005. Before formally launching the school feeding programme, the former President of Nigeria, Obasanjo, declared: "I foresee a day when Nigeria will be a nation with well-nourished and healthy children, happy and eager to attend school and complete their basic education in a friendly, conducive, attractive and stimulating learning environment". Twelve (12) States were selected by the Federal Government as pilot States for the programme and Osun State was one of them. Others are Bauchi, Edo, Enugu, FCT, Imo, Kano, Kogi, Nassarawa, Niger, Ogun and Yobe. The programme could have been an avenue for raising the literacy level in the country and give opportunity for more children to attain at least basic education. It is, however, worthy of note and disheartening that out of the twelve (12) pilot States, Osun State is the only State still implementing the programme (Adepoju 2010). All other States have abandoned it due to reasons best known to them. 


\section{Macrothink \\ Journal of Sociological Research \\ ISSN 1948-5468 \\ 2012, Vol. 3, No. 2}

\section{Lack of Continuity in Policy Implementation}

Various policies and programmes that have been introduced and which would have boosted pre-primary and primary education were not always continued by in-coming governments. Free education that was introduced in the West by the Unity Party of Nigeria (UPN) between 1979 and 1983 was discontinued by the National Party of Nigeria (NPN) under the guise of introducing qualitative education disallowed more children access to primary education.

\section{Politicization of Employment of Teachers into the Primary Schools and lack of Job satisfaction}

It is common knowledge that no nation can rise above the quality of her teachers. But it is very sad to note that appointment of teachers, especially into the pre-primary and primary, has been politicized. When those who are not sound academically are appointed, it automatically tells on the quality of education. On the other hand, most teachers see teaching as a stepping stone to other 'lucrative job'. Job satisfaction goes a long way in effective performance of such job. In a situation where a teacher feels he/she has no job is detrimental to proper development of education. Let us share this general impression about teaching as presented by the Presidential Task Team on Education (2011), titled "Get out of teaching and look for a job"

Box One:

\section{GET OUT OF TEACHING AND LOOK FOR A JOB}

- Suitor's family spokesman: A-salama-leikun, my people. May I introduce my young man, Ahmadu Tijani. Stand and be seen, Tijani

- Tijani (Standing): A-salama-leikun, my elders

- Spokesman : As you are well aware, we have come to ask for the hands of your daughter Amina, in Marriage

- Amina's Father: La-kuli-lai! Tijani has grown so big! Looks every inch like his grandfather. What does he do for a living?

- Tijani (timidly): I teach at Government Secondary School, Azare.

- Amina's Father: Huuum! Well, you are from a good family. I'll give my daughter, but.......LISTEN CAREFULLY

Promise me that you'll look for a job! 


\section{Round Pegs in Square Holes}

It is a common feature to see a lawyer or an engineer being appointed as the Commissioner for Education in some States in Nigeria. This has never helped in the quality and management of primary education. Is it because we do not have enough qualified professionals in the field of education? Politics! Education sector, especially the primary sub-sector needs professional touch and monitoring. Collation of data has also been politicized because of allocation of fund so that some people will have enough money to embezzle.

\section{Questionable Workshops and Seminars}

Workshops and seminars are in themselves very good and necessary to keep pace with current trends in educational practices all over the world. But it is becoming worrisome to note that current spate of workshops may not augur well with early childhood and primary education, it is becoming too frequent and often a money making venture. At times, it is the same sets of teachers who are 'connected' with coordinating officers that are invited to attend workshops thereby leaving the students unattended. There should be room for implementation of the learnt skills before they are called for another seminar, so as to make the whole exercise meaningful and worthwhile.

\section{Conclusion and Recommendations}

Human beings are generally referred to as political animals, society cannot be devoid of politics but it should be played for the progress of the society, especially as it touches sensitive sectors such as education. The state of pre-primary and primary education in Nigeria could be attributed to the poor politics that had been played and is being played. It is therefore recommended that;

More budgetary allocation should be devoted to education most especially to pre-primary and primary education and its disbursement properly monitored. Governments should stop paying lip service to the education sector. There is the need for more action in the area of infrastructure, supervision and monitoring to avoid unnecessary wastage and minimize corruption. Corruption should be seen and treated as a monster that deserves to be killed. We should look forward to a people like the Japanese who have a strong sense of shame, such that if they do anything shameful or wrong they would simply hide to commit suicide! They call it hara-kiri! (Kwakpovwe 2010:70). The fear of being exposed or disgraced forces them to put in their best in whatever they do. Even if they do not commit suicide they would try to display their shame by resignation or accepting severe punishment.

Just as the shortage of medical doctors in the hospital cannot result in the employment of over supplied administrative staff to perform surgery, teaching should be made more professional. The Teachers' Registration Council should be assisted to achieve the purpose of professionalizing teaching. In situations where pupils are even better than some teachers, no quality and 


\section{Al Macrothink}

Journal of Sociological Research

ISSN 1948-5468

2012, Vol. 3, No. 2

meaningful development is expected. Almost everybody now wants to be a teacher or a proprietor of 'International Nursery/Primary School' where the head teacher cannot speak fluently either in English or even in the local language.

I want to agree with the Presidential Task Team on Education (2011) that the most important issue is the political will to implement policies and recommendations in respect of education sector. Enough of committees, we need more action. EFA Goal number 2 talks about access i.e., "ensuring that by 2015 all children, particularly girls, children in difficult circumstances and those belonging to ethnic minorities, have access to, and complete free and compulsory Basic education of good quality" To this end, it was recommended in the EFA Report Card (2007) that; there should be free and compulsory basic education for all children of school age and, provision of mid-day meal to enhance children's access to, retention and completion of school cycle. A parent who does not enroll his/her child/ward in school contravenes section 2(2) of the UBE Act and therefore, commits an offence. How much of these have the government implemented. The Home Grown School Feeding and Health System should be made mandatory for all the States and FCT at least to allow the children of the poor to benefit a little from the resources of Nigeria.

Though it may be difficult in political administration not to appoint politicians as Commissioners or Ministers but it is possible to give appropriate portfolio to qualified persons. There should be National Policy on such appointments which must be followed and monitored, especially in Education sector.

\section{References}

Adepoju, D. (2010).Report on Home Grown School Feeding and Health Programme (HGSFP) in Osun State. (Unpublished Report).

ActionAid Nigeria (2006): From Grace to Grace: Management and Funding of Basic Education in Nigeria. Abuja: Action Aid Nigeria.

ActionAid Nigeria (2008): Little Beginnings, Noble Ends: CEF Catalysing the Achievement of MDG 2 and 3 in Nigeria. Abuja: Action Aid.

Adaralegbe, A. (1972): A Philosophy for Nigerian Education. Ibadan: Heinemann Educational Books (Nigeria) Ltd

Akanbi, G.O., Jekayinfa, A. A. \& Gabriel, A. O. (2010): From Traditions to Letters, Impact of the Changing Phases on childhood Education in Africa: The case of Pre-Colonial,

Colonial and Post Colonial Nigeria. International Journal of Research in

Education. 2(8) pp.126-134. 


\section{Macrothink}

Delors, J. (1996): Learning: The Treasure Within. Report to UNESCO of the International Commission on Education for the Twenty-First Century. France: UNESCO.

Fafunwa, A. B. (1974): History of Education in Nigeria. London: George Allen and Unwin.

Federal Ministry of Education (2007): Nigeria Education Sector Diagnosis: A Platform for Re-Engineering the Education Sector. Abuja

Federal Ministry of Education (2007): EFA (Nigeria) Report Card. Abuja

Federal Republic of Nigeria (2004): National Policy on Education. Lagos: NERDC PRESS.

Federal Republic of Nigeria (2007): National Policy for Integrated Early Childhood Development in Nigeria. Abuja.

Federal Republic of Nigeria (2009): Report of the Vision 2020 National Technical Working Group on Education Sector. Abuja.

Federal Republic of Nigeria (2011): Report of the Presidential Task Team on Education Main Report (Volume 1). Abuja: Federal Ministry of Education.

Guthrie, J. W. (Ed. 2003): Encyclopaedia of Education Second Edition. New York: Thomson Gale.

Igbuzor, O. (2006): The State Of Education in Nigeria. A Keynote Address delivered at a Roundtable by Civil Society Action Coalition on Education For All (CSACEFA) on $3^{\text {rd }}$ July. http://www.dawodu.com/igbuzor14.htm accessed 1/9/2011

Kwakpovwe, C. (2010): More than the Japanese Shame. Our Daily Manna. p.70

Moja, T. (2000): Nigeria Education Sector Analysis: An Analytical Synthesis of Performance and Main Issues. World Bank.

Nwagwu, A.N. (1993): Historical Development of Education Laws in Nigeria in Yoloye, E.A. (Ed.) Education and the Law. Abuja:Nigeria Academy of Education

Obanya, P.A.I. (2004): The Dilemma of Education in Africa. Ibadan: Heinemann Educational Books (Nigeria) Plc.

Obanya, P.A.I. (2007a): African Education in the EFA Decade. Ibadan: Mosuro Publishers.

Obanya, P.A.I. (2007b): Thinking and Talking Education. Ibadan: Evans Brothers (Nigeria Publishers) Limited. 
Olubodun, J.B.O. (2008): Universal Basic Education and Educational Reforms in Nigeria in: A.R. Lawal, S.A. Jimoh, S.A. Olorundare and Y.S. Ijaiya; Education Reforms in Nigeria Past, Present and Future. Ibadan: Stirling-Horden Publishers Ltd.

Osokoya, I.O. (1987): 6-3-3-4 Education in Nigeria History, Strategies, Issues and Problems. Lagos: Bisinaike Educational Publishers.

Osokoya, I.O. (1989): History and Policy of Nigerian Education in World Perspective. Ibadan: AMD Publishers.

Otonti, N. (1965): Western Education and the Nigerian Cultural Background. Ibadan: University Press Limited.

Penn, H. (2008): $\quad$ Early Childhood Education and Care in South Africa. $\quad$ www.cfbt.com accessed on-line June 23, 2010.

Taiwo, C.O. (1980): The Nigerian Educational System: Past, Present, and Future. Lagos: Thomas Nelson (Nigeria) Limited

The New Encyclopaedia Britanica fifteenth Edition 2003. Chicago: Encyclopaedia Britannica Inc. p.9.

Universal Basic Education Commission: Education For All is Responsibility for All. http://ubeconline.com/index.html accessed 1/9/2011

Ukeje, O. and Aisiku, J. U. (1982): Education in Nigeria in: A.B. Fafunwa and J.U. Aisiku (ed.) Education in Africa, A comparative survey London: George Allen and Unwin.

World Bank/Knowledge Networks; Early Childhood Development in Sub-Saharan Africa: Issues and Strategies. 